\title{
Application of the Hungarian Method for Assigning Workers to Ciptaland Development
}

\author{
Wosvo Aritonang, Nelly Astuti Hasibuan, Rivalri Kristianto Hondro \\ Department of Computer Science, STMIK Budi Darma, North Sumatera, Indonesia \\ Email: ${ }^{1}$ wosvoaritonang@gmail.com
}

\begin{abstract}
Assignment of workers is something that is needed by the company. But in reality the company is difficult to place its employees in each allocation. However, with the development of existing technology, this can be minimized by calculating the cost of each work and each allocation by utilizing existing data and extraction to produce new knowledge. The application of operational research techniques using the Hungarian method and tested using a system or application as a decision tree to assign some decent workers to be placed on jobs within the company. Therefore the author took the initiative to make a thesis entitled "Application of the Hungarian Method in Assigning Ciptaland Development Workers". The assignment process can show every worker by the company. So that Ciptaland Development can be a reference in making decisions in assigning and allocating workers. In this study, an Assignment model was made to determine the allocation of workers who were fit to be placed. This method is quite efficient in the allocation of workers. In applying this hungarian method can provide solutions or considerations for companies in making decisions.
\end{abstract}

Keywords: Hungarian Method, Worker, Project, Allocation

\section{INTRODUCTION}

Employees are an asset in a company where a worker must run a business activity, the role of a worker is very influential on the development of the company. To achieve company goals, employees are needed in accordance with company requirements. The company always strives to improve the performance of its workers, hoping that what the company's objectives will be achieved.

Ciptaland development that moves in the field of sales and installation of property materials. The mission of this company is to develop ideal, affordable, high quality residential areas and be able to provide added value for stakeholders. Ciptaland Development applies the WORID class management system. The company has an effective and efficient marketing and product sales system so that the ceiling installation services and property materials are optimally generated. Worker allocation is a problem regarding the arrangement of individuals (objects) to carry out tasks (activities), so that the costs incurred for the implementation of these allocations can be minimized. In general, the level of skills, work experience, educational background, and training of each worker is different, so that the completion time of the same worker varies. Therefore, it is necessary to allocate workers so that the work can be completed well so that the company can get the minimum profit. [1]

The work allocation process is usually carried out without further consideration of the costs involved and other aspects. Various jobs and facilities can be used to allocate workers. But the problem is how to determine which type of work should be done and allocated where workers are, so that the total cost is minimum. During this time, the allocation of workers in a project does not use certain considerations in providing work to workers. The foreman will usually give a new task to the worker when the work is done. However, there is no consideration for the costs involved in completing the project. [1]

The most appropriate special method for overcoming the Ciptaland Development worker assignment system is the hungarian method. This method is used to assist Ciptaland Development in the process of division of tasks and installation of property materials. In applying this method, rows and columns are modified in the effectiveness matrix until a single zero component appears in each row or column that can be selected as assignment allocation. All assignment allocations made are optimal allocations, and when applied to the initial effectiveness matrix, the minimum assignment is given.

\section{THEORY}

\subsection{Operational Research}

Operational research is a series of mathematical analysis and modeling activities for decision making purposes. Many managerial issues in an organization / company that are always associated with the decision making process (decision making). Although the main purpose of operational research is to obtain optimal solutions, managerial practices are more important in satisfying solutions. Decisions in business are still more determined by the behavior 
of the decision maker (whether he is an optimistic or pessimistic, brave and afraid of risk). Quantitative and systematic analysis is still needed as a basis for arguments that can be rationally accounted for [2].

\subsection{Assignment}

The assignment problem (assignment problem) is a problem regarding setting objects to carry out tasks, with the aim of minimizing costs, time, distance and so on or maximizing profits that one of the solutions using the Hungarian method. So that it can be described as in Figure 1 [3].

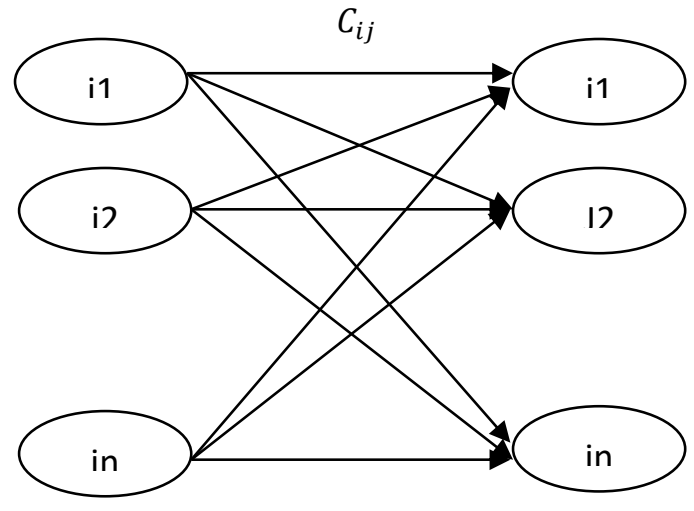

Figure 1. Establishment of Assignment Value

\subsection{Hungarian Method}

Prawisento, revealed the Hungarian method is a method that modifies rows and columns in the effectiveness matrix until a single zero component appears in each row or column that can be selected as assignment allocation. All assignment allocations made are optimal allocations, and when applied to the initial effectiveness matrix, will provide the minimum assignment results. [3]. The assignment problem can be solved using the Hungarian method of the following steps

1. Modify the assignment table into the effectiveness matrix. Where this matrix is formed to facilitate the completion of each step of the method that has been done.

2. Select the smallest value of each row, then subtract the operation of each value in line with the smallest number selected. Thus, it is certain that there is at least one Elementt in each matrix row that is zero and there are no Elementts with negative values.

3. Conduct column subtraction if there are columns that do not yet have Elementt 0, ie select the smallest value from the column, then a subtraction operation is performed from each column value with the smallest number selected.

4. Form the optinum assignment by drawing a number of horizontal and / or vertical lines that pass through all cells that have a value of 0 .

5. Revise the table by selecting the smallest value that is not crossed by the line.

6. Assignments are placed in cells with a value of 0 . Where each number 0 is replaced by number 1 but each column and row only has one assignment Elementt.

7. Calculating the total value of the solution obtained based on Elementts of the initial matrix that have not been reduced in value so that the total value of optinum is obtained.

\section{RESULT AND DISCUSSION}

Problem analysis is an attempt to describe the patterns consistently in the data by outlining its constituent components or arranging these components for further study. Analysis of the problem applied to the Ciptaland Development employee assignment process. Ciptaland Develodment is one of the companies engaged in the installation of property materials. In carrying out its business the company carries out a division in the field of installation of property materials. By looking at the project data installation of property materials, and area data. After the data is collected then proceed with analyzing how to determine which workers are eligible to be placed in a property installation project. This makes it difficult for the company in assigning a worker and requires a long time to analyze and determine who deserves to be assigned to a particular job. Based on the problems mentioned above, we need a method that is able to solve the assignment problem to determine who is suitable to be assigned to each part of the job with the minimum cost of work. 
In terms of determining the division of labor duties, the company does the division of workers into several parts of the project location, each location is done by a worker. The steps taken in the assignment of Ciptaland Development workers can be described as follows:

1. Check the number of workers and locations that will be occupied in each project or location.

2. Conducting the division of labor by looking at the large number of housing in each location which is then divided by the number of existing workers. Determination of the number of workers installing property is done manually where each project is assigned by the leadership of the company to carry out the work to each housing location. The work process assigned by the leadership does not yet have the right method to overcome the problem of assigning the worker.

3. The division of workers is carried out evenly by the leadership of the company for each project. Appointment of workers is done manually by operational results data managed by Ciptaland Development.

In the case of Assignment of Workers to be processed using the Hungarian method. Potential methods for determining assignment cases with optimal results. The data used is a recapitulation of operational costs submitted and approved by the company in 2016 described as follows:

1. Project data and location to be assigned to the property installation process.

Table 1. Project Data Being Implemented

\begin{tabular}{ccc}
\hline NO & Type Of Project & Location \\
\hline 1 & Ceiling Installation & Malibu Indah \\
2 & Installation of Antique Motifs & Namorambe City \\
3 & Ceramic Installation & Graha Brayan \\
4 & Build Foundations & Perumnas Mandala \\
5 & Water Pipe Installation & Cemara Asri \\
6 & Roof Installation & Turi Mansion \\
\hline
\end{tabular}

2. The data analyzed in this study are data on the cost of each work to be bought up for the Property Installation Project at each location.

Table 2. Data on Job Project Wholesale Costs

\begin{tabular}{lccccc}
\hline \multicolumn{1}{c}{ Worker Name } & $\begin{array}{c}\text { Ceiling } \\
\text { Installation }\end{array}$ & $\begin{array}{c}\text { Installation of } \\
\text { Antique Motifs }\end{array}$ & $\begin{array}{c}\text { Ceramic } \\
\text { Installation }\end{array}$ & $\begin{array}{c}\text { Build } \\
\text { Foundations }\end{array}$ & $\begin{array}{c}\text { Wall Mounting } \\
\text { Installation }\end{array}$ \\
\hline Jekroniko & $7,000,000$ & $8,000,000$ & $6,000,000$ & $5,500,000$ & $7,000,000$ \\
Apostel & $4,500,000$ & $6,000,000$ & $5,500,000$ & $8,000,000$ & $6,500,000$ \\
Kasio & $8,000,000$ & $7,000,000$ & $5,500,000$ & $6,500,000$ & $7,000,000$ \\
Adi Septianto & $7,500,000$ & $6,000,000$ & $8,000,000$ & $5,000,000$ & 6,000 \\
Tommy Bondar & $6,000,000$ & $6,500,000$ & $6,000,000$ & $4,500,000$ & $5,000,000$ \\
Koko & $5,000,000$ & $5,000,000$ & $5,000,000$ & $6,000,000$ & $5,000,000$ \\
\hline
\end{tabular}

Based on table 2. the process of solving the assignment problem only considers the total cost of the worker so that the total cost of the worker can be optimized. In the Employee Assignment process, its characteristics are consistent with the assignment problem, with the following conditions:

1. The number $\mathrm{i}$ must be equal to the number $\mathrm{j}$ that must be completed.

2. Each source only does one task.

3. If the number of sources does not equal the number of tasks or vice versa, then the dummy woker or dummy job variable is added.

4. There are problems that are resolved, namely minimizing losses (cost, time, distance and so on) or maximizing profits.

The recapitulation matrix for the number of searches makes it easier for the compiler to process the data in Ciptaland Development to be presented in the matrix calculation process using the data. We will look for a simplification solution into the matrix form below:

Number of Search Recapitulation Matrix:

$\left(\begin{array}{llllll}7.000 .000 & 8.000 .000 & 6.000 .000 & 5.500 .000 & 7.000 .000 & 8.500 .000 \\ 4.500 .000 & 6.000 .000 & 5.500 .000 & 8.000 .000 & 6.500 .000 & 4.000 .000 \\ 8.000 .000 & 7.000 .000 & 5.500 .000 & 6.500 .000 & 7.000 .000 & 5.000 .000 \\ 7.500 .000 & 6.000 .000 & 8.000 .000 & 5.000 .000 & 6.000 .000 & 3.000 .000 \\ 6.000 .000 & 6.500 .000 & 6.000 .000 & 4.500 .000 & 5.000 .000 & 5.000 .000 \\ 5.000 .000 & 5.000 .000 & 5.000 .000 & 6.000 .000 & 4.000 .000 & 8.000 .000\end{array}\right)$

The solution for determining the hungarian method calculation is completed by modifying the assignment table into the matrix using the Hungarian method with the following steps :

1. The cost matrix must be square. 
Square matrix is a matrix that has the order $\mathrm{n} \times \mathrm{n}$ or the number of rows equal to the number of columns contained in the matrix. This matrix is also called a square matrix with order $\mathrm{n}$. The square matrix to find the number of search results Cost of workers by simplifying data can be seen in the matrix below

Cost Matrix

$$
\left(\begin{array}{llllll}
7.000 & 8.000 & 6.000 & 5.500 & 7.000 & 8.500 \\
4.500 & 6.000 & 5.500 & 8.000 & 6.500 & 4.000 \\
8.000 & 7.000 & 5.500 & 6.500 & 7.000 & 5.000 \\
7.500 & 6.000 & 8.000 & 5.000 & 6.000 & 3.000 \\
6.000 & 6.500 & 6.000 & 4.500 & 5.000 & 5.000 \\
5.000 & 5.000 & 5.000 & 6.000 & 4.000 & 8.000
\end{array}\right)
$$

To further simplify the process of solving the assignment problem by the Hungarian method can be done in the manner below.

2. Determine the smallest value of each row

Subtract the Elementt with the smallest value in each row with all Elementts in that row. The work steps are as follows:

a. The smallest Element in line 1 is 5.500

Element $(1,1)=7.000-5.500=1.500$

Element $(1,2)=8.000-5.500=2.500$

Element $(1,3)=6.000-5.500=500$

Element $(1,4)=5.500-5.500=0$

Element $(1,5)=7.000-5.500=1.500$

Element $(1,6)=8.500-5.500=3.000$

b. The smallest Element in line 2 is 4.000

Element $(2,1)=4.500-4.000=500$

Element $(2,2)=6.000-4.000=2.000$

Element $(2,3)=5.500-4.000=1.500$

Element $(2,4)=8.000-4.000=4.000$

Element $(2,5)=6.500-4.000=2.500$

Element $(2,6)=4.000-4.000=0$

c. The smallest Element in line 3 is 5.000

Element $(3,1)=8.000-5.000=3.000$

Element $(3,2)=7.000-5.000=2.000$

Element $(3,3)=5.500-5.000=5.00$

Element $(3,4)=6.500-5.000=1.500$

Element $(3,5)=7.000-5.000=2.000$

Element $(3,6)=4.000-5.000=0$

d. The smallest Element in line 4 is 3.000

Element $(4,1)=7.500-3.000=4.500$

Element $(4,2)=6.000-3.000=3.000$

Element $(4,3)=8.000-3.000=5.000$

Element $(4,4)=5.000-3.000=2.000$

Element $(4,5)=6.000-3.000=3.000$

Element $(4,6)=3.000-3.000=0$

e. The smallest Element in line 5 is 4.500

Element $(5,1)=6.000-4.500=1.500$

Element $(5,2)=6.500-4.500=2.000$

Element $(5,3)=6.000-4.500=1.500$

Element $(5,4)=4.500-4.500=0$

Element $(5,5)=5.000-4.500=500$

Element $(5,6)=5.000-4.500=500$

f. The smallest Element in line 6 is 4.000

Element $(6,1)=5.000-4.000=1.000$

Element $(6,2)=5.000-4.000=1.000$

Element $(6,3)=5.000-4.000=1.000$

Element $(6,4)=6.000-4.000=2.000$

Element $(6,5)=4.000-4.000=0$

Element $(6,6)=8.000-4.000=4.000$

After this process the $\mathrm{M}$ matrix changes to: 


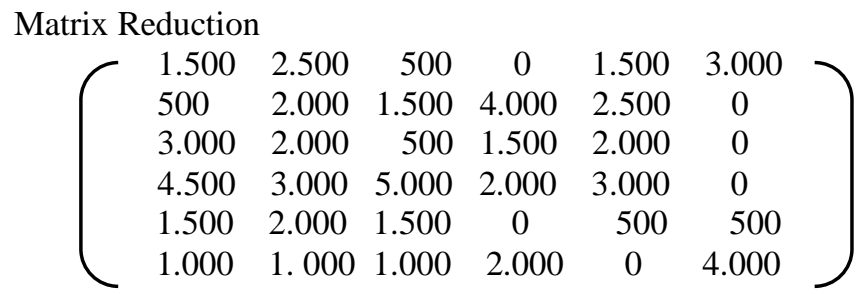

3. Check whether each column already has the number 0 . If you do not already have a value of 0 , then determine the smallest value in each column that does not yet have an Element that has a value of 0, then each Element value in the column is reduced by the smallest value. In the matrix above in column 1 and column 5 do not yet have Element value 0. Then continue the work steps as follows:

a. The smallest element in the column 1 is 500

Element $(1,1)=1.500-500=1.000$

Element $(2,1)=5.00-500=0$

Element $(3,1)=3.000-500=2.500$

Element $(4,1)=4.500-500=4.000$

Element $(5,1)=1.500-500=1.000$

Element $(6,1)=1.000-500=500$

b. The smallest element in the column 2 is 1.000

Element $(1,2)=2.500-1.000=1.500$

Element $(2,2)=2.000-1.000=1.000$

Element $(3,2)=2.000-1.000=1.000$

Element $(4,2)=3.000-1.000=2.000$

Element $(5,2)=2.000-1.000=1.000$

Element $(6,2)=1.000-1.000=0$

c. The smallest element in the column 3 is 500

Element $(1,3)=500-500=0$

Element $(2,3)=1.500-500=1.000$

Element $(3,3)=500-500=0$

Element $(4,3)=5.000-500=4.500$

Element $(5,3)=1.500-500=1.000$

Element $(6,3)=1.000-500=500$

After this process the $\mathrm{M}$ matrix changes to:

Matrix Assignment

$$
\left(\begin{array}{cccccc}
1000 & 1.500 & 0 & 0 & 1.500 & 3.000 \\
0 & 1.000 & 1.000 & 400 & 2.500 & 0 \\
2.500 & 1.000 & 0 & 1.500 & 2.000 & 0 \\
4.000 & 2.000 & 4.500 & 2.000 & 3.000 & 0 \\
1.000 & 1.000 & 1.000 & 0 & 500 & 500 \\
500 & 0 & 500 & 2.000 & 0 & 4.000
\end{array}\right)
$$

4. Make checks, By forming the optimum assignment of drawing a number of horizontal and or vertical lines that pass through cells that are zero. If the number of lines equals the number of rows / columns, the assignment is optimal. If not then it must be revised.

5. Check, see the position of the value that has not been hit by the line. Select the smallest value (from the picture above is 500), then the value 500 is used to subtract other values that have not been hit by the line, and add the numbers that have crossing lines.

Revision of the Assignment Table

$$
\left(\begin{array}{cccccc}
1.500 & 1.500 & 0 & 0 & 1.500 & 800 \\
0 & 1.000 & 1.000 & 400 & 2.500 & 500 \\
2.500 & 1.000 & 0 & 1.500 & 2.000 & 500 \\
3.500 & 1.500 & 4.000 & 1.500 & 2.500 & 0 \\
500 & 500 & 500 & 500 & 0 & 500 \\
500 & 0 & 500 & 2.000 & 0 & 3.500
\end{array}\right)
$$

6. Checking, see the position of the Elements that have a value of 0 . Where each number 0 is replaced by the number 1 but each column and row only has one number 1 as an assignment. 
Assignment Matrix

$\left(\begin{array}{rrrrrr}1.500 & 1.500 & 0 & 0(1) & 1.500 & 800 \\ 0(1) & 1.000 & 1.000 & 400 & 2.500 & 500 \\ 2.500 & 1.000 & 0(1) & 1.500 & 2.000 & 500 \\ 3.500 & 1.500 & 4.000 & 1.500 & 2.500 & 0(1) \\ 500 & 500 & 500 & 500 & 0(1) & 500 \\ 500 & 0(1) & 500 & 2.000 & 0 & 3.500\end{array}\right)$

Based on the matrix above, a suitable solution can be determined to be placed in each Ciptaland Development project location as follows:

a. Worker 1 is suitable for allocation to allocation 4 with a work cost of Rp.5,500,000

b. Worker 2 is suitable to be allocated to allocation 1 with a work cost of IDR 4,500,000

c. Worker 3 is suitable for allocation to allocation 3 with a work cost of Rp.5,500,000

d. Worker 4 is suitable for allocation to allocation 6 with a work cost of Rp. 3,000,000

e. Worker 5 is suitable for allocation to allocation 5 with a work cost of IDR 5,000,000

f. Worker 6 is suitable for allocation to allocation 2 with a work cost of IDR 5,000,000

Then it can be concluded with the Hungarian method the Ciptaland Development company can see the opportunities of a worker in the installation of property materials. With a total installation cost of the project is $\mathrm{Rp}$. $28,500,000$

\section{IMPLEMENTATION}

Implementation stage is the stage where the application that has been analyzed, will be tested and operated in accordance with the functions and objectives of the desired. The following is an explanation of the implementation of the POM QM application for Windows version 3.0

The results of the application display results from the Hungarian method for the assignment of Ciptaland Development workers can be seen in the picture below:

initial display that will appear when you first run the POM QM application for windows. The main menu display can be seen below.

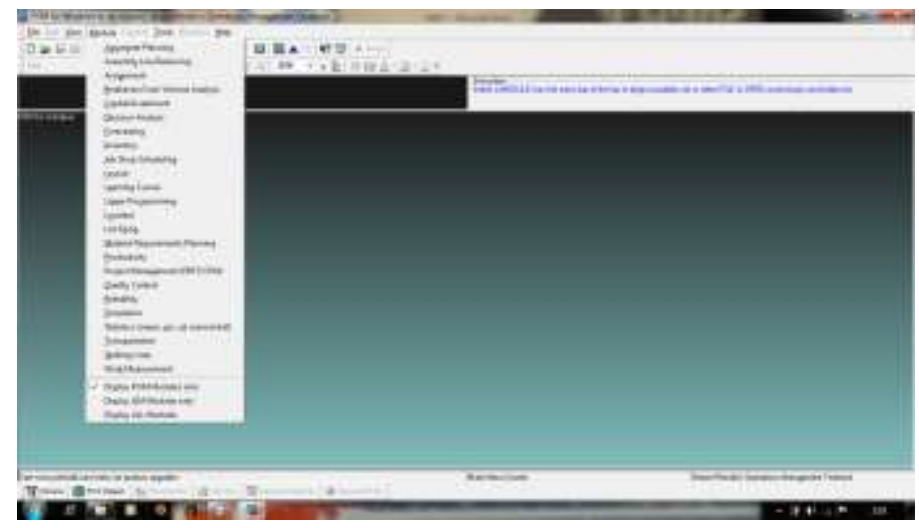

Figure 1. Main Menu

In running the Pom QM for windows program, select Module-Decision Analysis, select the File-New menu, fill in the number of constraints 6 by clicking the arrow in the number of constraints box and then proceed to fill in the number of variables 6 so that the display appears below this:

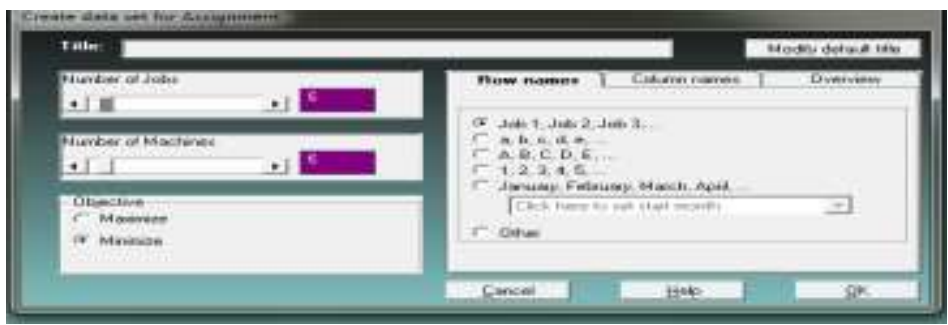

Figure 2. Initial display of Decision Analysis 
The IJICS (International Journal of Informatics and Computer Science) Vol 4 No 1, March 2020

ISSN 2548-8384 (online) ISSN 2548-8449 (print)

Page $12-19$

DOI 10.30865/ijics.v4i1.1983

After filling in the number of constraints and the number of variables, the next step is to fill in the cost of work volume data from the picture above. Then it will appear as shown below:

\begin{tabular}{|c|c|c|c|c|c|c|c|c|c|c|c|}
\hline File Edit View & Module & Format & Iools & Windov & w & elp & & & & & \\
\hline 口曰回星 & 䠉 喝 & 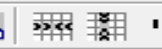 & " Títle & 苗望监 & 苗 & $10 \%$ & 回 & 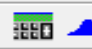 & $a_{2}$ & A? ? & Solve \\
\hline A.rial & & - & $8.25-1$ & B $I$ & $\underline{\mathbf{U}}$ & $\underline{\underline{\underline{\underline{\underline{\underline{ }}}}}} \overline{\overline{\underline{\underline{\underline{\underline{a}}}}}}$ & $\bar{\equiv}$ & .00 & - & , Fix & 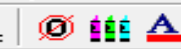 \\
\hline $\begin{array}{l}\text { Objective } \\
\text { C. Maximize } \\
5 \text { Minimize }\end{array}$ & & & & & & & $\begin{array}{l}\text { Instruc } \\
\text { Enter }\end{array}$ & ction - & of assi & gning jek & kroniko to peme \\
\hline & & & & & & & & & & & \\
\hline & & Pemasangan & Pemas & sangan & Pema & sangan & memb & bangun & Pemas & angan & pemasangan \\
\hline Jekroniko & & 7000000 & & 000000 & & 000000 & & 500000 & & 00000 & 8500000 \\
\hline Apostel & & 4500000 & & 000000 & & 500000 & & 00000 & & 00000 & 4000000 \\
\hline Kasio & & 8000000 & & 000000 & & 500000 & & 500000 & & 00000 & 5000000 \\
\hline Adi Septianto & & 7500000 & & 000000 & & 000000 & & 000000 & & 00000 & 3000000 \\
\hline Tommy bondar & & 6000000 & & 500000 & & 000000 & & 500000 & & 00000 & 5000000 \\
\hline Koko & & 5000000 & & 000000 & & 000000 & & 000000 & & 00000 & 8000000 \\
\hline
\end{tabular}

Figure 3. Display Data Input Form

Display the test results Assigning the output by filling in the Data Input Form and then clicking Solve, the results will appear with 3 output Assignments, such as the image below:

1. Output Assignments, in this output there are 6 columns and 6 rows already have each assignment

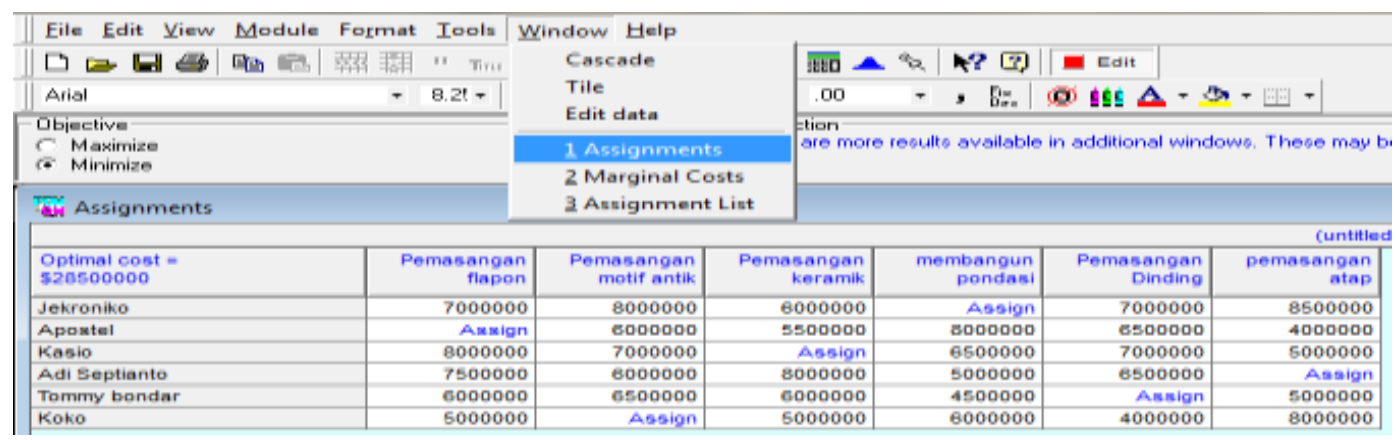

Figure 4. Output Assignment

2. Output Marginal Cost, an increase in total costs originating from one unit of output.

Marginal Costs
\begin{tabular}{|l|r|r|r|r|r|r|}
\hline \multicolumn{1}{|l|}{$\begin{array}{r}\text { Pemasangan } \\
\text { flapon }\end{array}$} & $\begin{array}{r}\text { Pemasangan } \\
\text { motif antik }\end{array}$ & $\begin{array}{r}\text { Pemasangan } \\
\text { keramik }\end{array}$ & $\begin{array}{r}\text { membangun } \\
\text { pondasi }\end{array}$ & $\begin{array}{r}\text { Pemasangan } \\
\text { Dinding }\end{array}$ & $\begin{array}{r}\text { pemasangan } \\
\text { atap }\end{array}$ \\
\hline & 0 & 1000000 & 500000 & & 1000000 & 45000000 \\
\hline Jekroniko & & 1500000 & 2500000 & 5000000 & 3000000 & 2500000 \\
\hline Apostel & 1000000 & & & 1000000 & 1000000 & 1000000 \\
\hline Kasio & 1500000 & & 3500000 & 500000 & 1500000 & \\
\hline Adi Septianto & 0 & 500000 & 1500000 & & & 2000000 \\
\hline Tommy bondar & & & 1500000 & 2500000 & & 6000000 \\
\hline Koko & & & &
\end{tabular}

Figure 5. Output Marginal Cost

3. Output Assignment List, Shows the placement of each person on the job and its costs:

\begin{tabular}{|l|r|r|}
\hline JOB & $\begin{array}{r}\text { Assigned } \\
\text { to }\end{array}$ & Cost \\
\hline Jekroniko & membangun & 5500000 \\
\hline Apostel & 'emasangan & 4500000 \\
\hline Kasio & 'emasangan & 5500000 \\
\hline Adi Septianto & Jemasangan & 3000000 \\
\hline Tommy bondar & 'emasangan & 5000000 \\
\hline Koko & 'emasangan & 5000000 \\
\hline Total & & 28500000 \\
\hline
\end{tabular}

Figure 6. Output Assigment List

Based on Figure 6. Output Assigment List above, a suitable solution can be determined to be placed in each Ciptaland Development project location as follows: 
a) Jekroniko is assigned to a work project to build a foundation at a cost of Rp.5,500,000

b) Apostel is assigned to the flapon installation project at a cost of Rp.4,500,000

c) The ratio is assigned to the ceramic installation project at a cost of Rp.5,500,000

d) Adi Septianto was assigned to the roof installation project at a cost of Rp. 3,000,000

e) Tommy Bondar is assigned to the wall installation project at a cost of Rp. 5,000,000

f) Koko was assigned to the antique motif installation project at a cost of Rp.5,000,000

Then it can be concluded with the existence of the QM POM application for windows the company Ciptaland Development can see the opportunities of a worker in the installation of property. With a total installation cost of the project is Rp. $28,000,000$

\section{CONCLUSION}

Based on the results of the discussion that has been described and after completing research on Ciptaland Development, the authors draw some conclusions as follows:

1. With the process of assigning Ciptaland Development workers to each different location and determining minimum costs can help in the assignment of workers to Ciptaland Development.

2. The application of the Hungarian Method to Ciptaland Development workers can provide more accurate results to any workers who will be assigned to different locations.

3. By testing the Hungarian Method in the QM For Windows Application can help the assignment of Ciptaland Development workers to use as a reference in decision making.

\section{REFERENCES}

[1] F. T. Waruwu, A. Yanny dan E. Ndruru, "Alokasi Pekerja Pada Suatu Proyek Dengan Metode Hungarian," KOMIK, vol. 1, no. 1, pp. 215-219, Oktober 2017.

[2] B. A. Noer, Belajar Mudah Riset Operasional, 1 penyunt., R. Fiva, Penyunt., Yogyakarta: C.V Andi OFFSET, 2010.

[3] J. D. P. M. Paendong, “Optimasi Pembagian Tugas Karyawan Menggunakan Metode Hungarian,” Jurnal Ilmiah sains, vol. 11, pp. 109-115, April 2011.

[4] R. Andrilla, "Penerapan Stakeholder Relationship Management Plus (SRM+) Dalam Pengelolahan Community Di Area Operasional Total E\&P Indonesie," eJournal Ilmu Komunikasi, vol. 2, no. 3, pp. 333346, 2014.

[5] B. Sihabudin, "Peran Serikat Pekerja Dalam Perlindungan Hak-Hak Pekerja Di CV. Triona Multi Industri," Jurnal Kapemda, vol. 11, no. 6, pp. 95-113, 2017.

[6] N. Eliyati, O. H. Marbun dan N. R. Dewi, "Kajian Struktur Aljabar Grup Pada Himpunan Matriks Yang Invertibel," Jurnal Penelitian Sains, vol. 14, no. 1, pp. 1-3, 2011.

[7] Diaraya, "Desain Flowchart Pemrosesan Transaksi Perubahan Pada Sistem Informasi akuntasi Berbasis Komputer," urnal Matematika, Statistika \& Komputasi, vol. 13, no. 2, pp. 141-146, 2017.

[8] S. Rosihan Asmara dan D. N. Hanani, "Metode Kuantitatif Bahan Pelatihan QM For Windows," Januari 2010. [Online]. Available: http://anzdoc.com/metode-kuantitatif-bahan-pelatihan-qm-for-windows-linearpro.html. [Diakses April 2018]. 